\title{
Electro Oxidation of Methanol at Pt/Au/Sn Triplet Electrode
}

\author{
Mohamed Abdelfattah Ibrahim ${ }^{1,2^{*}}$ and Ali Moulahi ${ }^{1}$ \\ 'Department of Chemistry, Al-Wajha University College, University Of Tabuk, Tabuk, Saudi Arabia; \\ science1712@gmail.com, mohamedfattah2002@yhoo.com \\ 2Department of Chemistry, Faculty of Science, El-Arish University, North Sinai, Egypt
}

\begin{abstract}
Objectives: To find a novel and a cheap anode for direct methanol fuel cell that resists the poisoning by carbon monoxide produced inside the cell. Methods/Statistical Analysis: We prepare triplet electrode by using electrodeposition technique in nano-scale to improve the overall electro-catalytic properties of anode towards electrochemical oxidation of methanol. Findings: The prepared nano-anode is better than the traditional electrode $\mathrm{Pt} / \mathrm{Au}$ because the triplet anode $\mathrm{Pt} / \mathrm{Au} / \mathrm{Sn}$ give higher current density in low over potential. Application/Improvements: There exist many applications of this triplet nano-anode in portable devices, cars, vehicles, airplanes and space shuttles.
\end{abstract}

Keywords: Cyclic Voltammogram (CV), Direct Methanol Fuel Cell (DMFCs), Electrochemical Oxidation, Methanol, Scanning Electron Microscope, Triplet Electrode

\section{Introduction}

Methanol fuel cells are very important because they are potentially highly efficient and clean energy systems with technological applications ${ }^{1,2}$. There is many improvements that have been made in the performance of DMFCs ${ }^{3,4}$ but still not widespread applied. The limitations mainly arise from electrocatalytic activity of both anode $^{5-7}$ and cathode ${ }^{8,9}$ catalysts, and high cost of anode specially Pt. Therefore, much effort has been devoted to increase the performance of the catalysts ${ }^{10-13}$. Now, more attention paid on bimetallic anode ${ }^{14,15}$ because they have better catalytic activity than the separate metals ${ }^{16-18}$. The platinum modified by gold electrode, has high catalytic activity towards methanol oxidation ${ }^{19-24}$. Gold has uniform coverage on $\mathrm{Pt}$, so decreases Pt dissolution during methanol oxidation ${ }^{25}$.

Moreover, $\mathrm{Au}$ increases the catalytic activity that involves the tolerance of adsorbed poisonous species and a change in electronic band structure to modify the strength of the surface adsorption ${ }^{26}$. The $\mathrm{Pt}-\mathrm{Au}$ catalysts have superior $\mathrm{CO}$ oxidation activity and $\mathrm{CO}$ tolerance ability in comparison with their separate metal ${ }^{27-29}$.
In this study we test triplet electrode of $\mathrm{Pt} / \mathrm{Au} / \mathrm{Sn}$ nanoparticles for electrooxidation of methanol in fuel cell.

\section{Experimental Techniques}

\subsection{Solutions}

We used double distilled water for preparation of the electrolytes solutions and ultra pure chemicals: sulfuric acid (BDH), sodium bicarbonate (BDH), methanol (Merck), stannous sulfate (Merck), and gold trichloride (Merck). We purged ultra-pure nitrogen for all electrolytic solutions.

\subsection{Instrumentation and Cell}

We used Saturated Calomel Electrode (SCE) as a reference electrode and a gold wire as a counter electrode. All electrochemical measurements are done by using three compartment electrochemical cell.

Electrochemical measurements were performed using a potentio glvanostate model Wenking PS 95. 
Samples for TEM examined by using a JEOL 2010 transmission electron microscopy operated at $200 \mathrm{kV}$.

\subsection{Preparation of Working Electrode}

\subsubsection{Preparation of Pt Modified Au Electrode}

The steady state of Pt electrode was checked by cyclic voltammetry in $0.1 \mathrm{M} \mathrm{H}_{2} \mathrm{SO}_{4}$, $\mathrm{Au}$ nano-particles was deposited from $10^{-3} \mathrm{M} \mathrm{AuCl}_{3}$ in $0.1 \mathrm{M} \mathrm{H}_{2} \mathrm{SO}_{4}$.

The electrode position process was performed by cycling the Pt substrate between $-0.25 \mathrm{~V}$ to $1.15 \mathrm{~V} / \mathrm{SCE}$ using nano-membrane. The modified electrode, referred as $\mathrm{Pt}-\mathrm{Au}$ electrode, was checked by cycling the electrode in $0.1 \mathrm{M} \mathrm{H}_{2} \mathrm{SO}_{4}$.

\subsubsection{Real Surface Area Determination}

Pt surface area $\left(\mathrm{S}_{\mathrm{Pt}}\right)$ determined from the hydrogen adsorption/desorption region ${ }^{30,31}$ in the voltammogram of platinum in $0.1 \mathrm{M}$ sulfuric acid Figure 1. The percentage of $\mathrm{Pt}$ to $\mathrm{Au}$ determined from the hydrogen region according to the following equation

$$
\% \mathrm{Pt}=\left(\mathrm{Q}_{\mathrm{Pt} / \mathrm{Au}}^{\mathrm{H}} / \mathrm{Q}_{\mathrm{Pt}}^{\mathrm{H}}\right) \times 100
$$

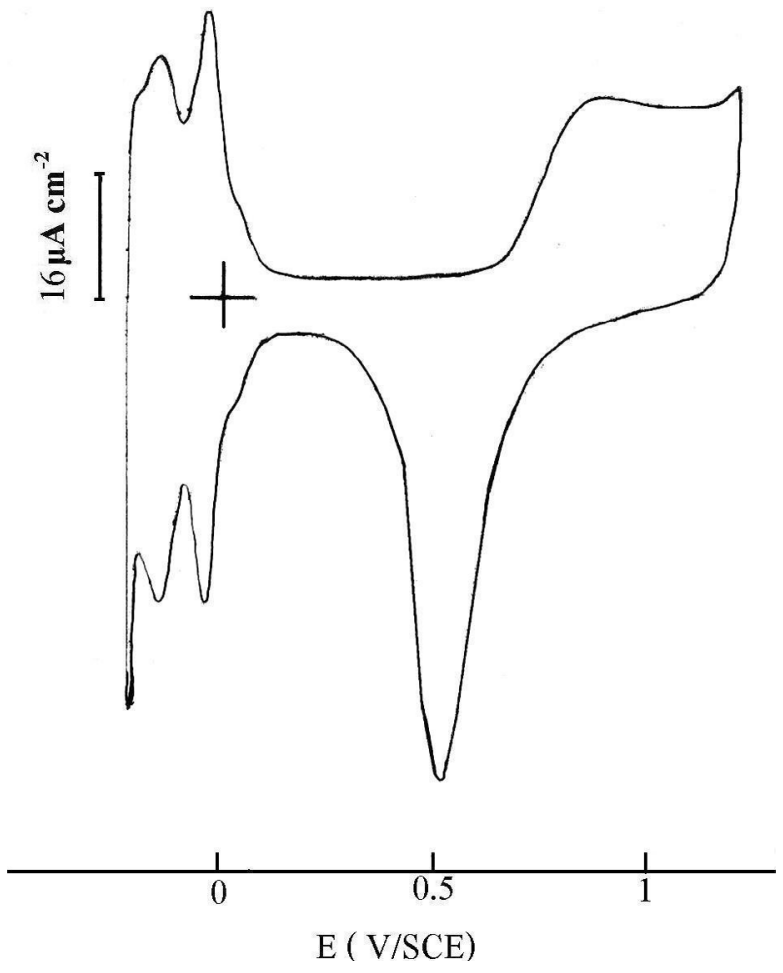

Figure 1. Cyclic voltammogram of Pt electrode in $0.1 \mathrm{M}$ $\mathrm{H}_{2} \mathrm{SO}_{4}$. Scan rate $50 \mathrm{mV} \mathrm{s}^{-1}$.
Where $\mathrm{Q}_{\mathrm{Pt}}^{\mathrm{H}}$ and $\mathrm{Q}_{\mathrm{Pt} / \mathrm{Au}}^{\mathrm{H}}$ are the charges for hydrogen adsorption in the absence and the presence of deposited gold.

\subsection{Cyclic Voltammetry}

The experiments were performed according to the following procedure:

- The steady state cyclic voltammogram of platinum was recorded in supporting electrolyte.

- Metal ion solution was added to the electrolytic solution to prepare the desired metal ion concentration and a new voltammogram was recorded.

- The required amount of the methanol was introduced to the cell and the steady-state voltammogram was recorded.

\section{Results and Discussion}

\subsection{TEM Analysis}

Figure 2(a) demonstrates the distribution of gold nanoparticles on platinum. Figure 2(b) shows the composition of Pt-0.5Au TEM images. In the $\mathrm{Pt} / \mathrm{Au}$ nanoparticles, the high coverage and similar surface particle coverage. The Au nanoparticles dispersed very well on Pt.

The decreased widths of distributions indicate that no new additional nucleation goes on platinum during the formation of $\mathrm{Pt} / \mathrm{Au}$ nanoparticles.

\subsection{Oxidation of Methanol on Au@Pt Anode in 0.1M Sodium Bicarbonate}

Figure 3 shows the dependence of peak current density on the composition of Pt-Au electrodes. As can be shown from this Figure the best composition is $40 \% \mathrm{Au}$. This activity due to the synergistic effect ${ }^{32-36}$.

\subsection{Platinum/Gold/ $/ \mathrm{Sn}_{\text {ad-atoms }}$ Modified Electrodes in $\mathrm{NaHCO}_{3}$}

Figure 4 represents the effect of $10^{-5} \mathrm{M} \mathrm{Sn}^{2+}$ on the voltammograms of Au@Pt. As shown from this figure the upd process of $\mathrm{Sn}$ in $0.1 \mathrm{M} \mathrm{NaHCO}$ begins at $0 \mathrm{~V} /$ SCE. Its re-dissolution occurs mainly in a single peak at $-0.05 \mathrm{~V} / \mathrm{SCE}$. 

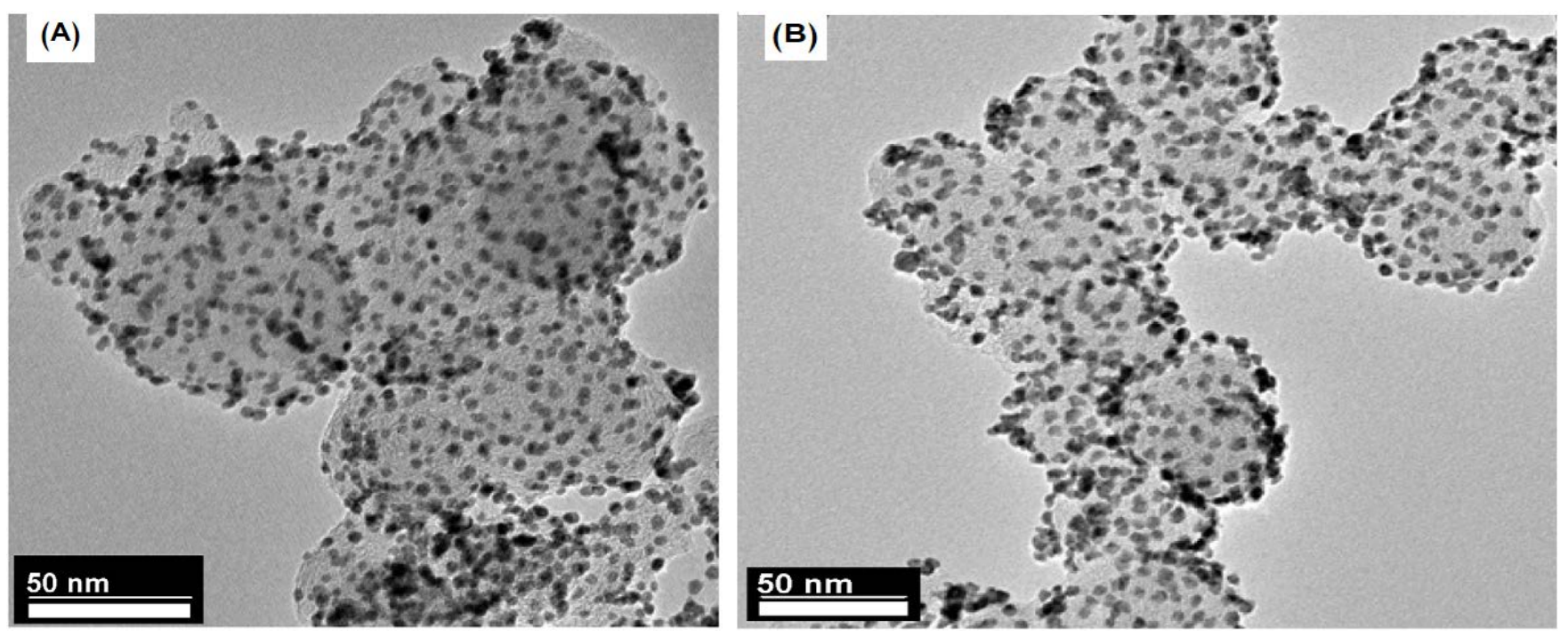

Figure 2. TEM images for (a) Pt/ 0.4Au nanoparticles. (b) Pt/ $0.5 \mathrm{Au}$ nanoparticles.

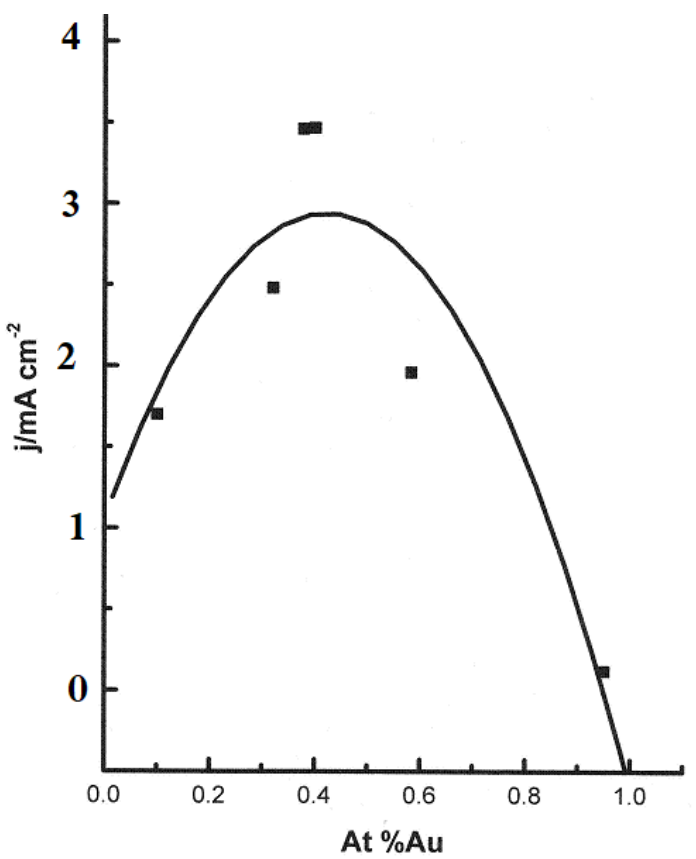

Figure 3. Dependence of the peak current density on the $\mathrm{Pt}$ region on the alloy compositions for $\mathrm{Pt} / \mathrm{Au}$ in $0.5 \mathrm{M}$ $\mathrm{CH}_{3} \mathrm{OH}+0.1 \mathrm{M} \mathrm{NaHCO}_{3}$.

\subsection{Oxidation of Methanol at Platinum/ Gold/Sn $n_{\text {ad-atoms }}$ Anode in $\mathrm{NaHCO}_{3}$}

Figure 5 shows the oxidation of methanol at $\mathrm{Pt} / \mathrm{Au} / \mathrm{Sn}$ anode. We found that $\mathrm{Sn}$ ions increase the catalytic activity of $\mathrm{Pt} / \mathrm{Au}$ electrode at all metal concentrations accompanied by a shift of the peak potential by around $140 \mathrm{mV}$ to the positive direction.

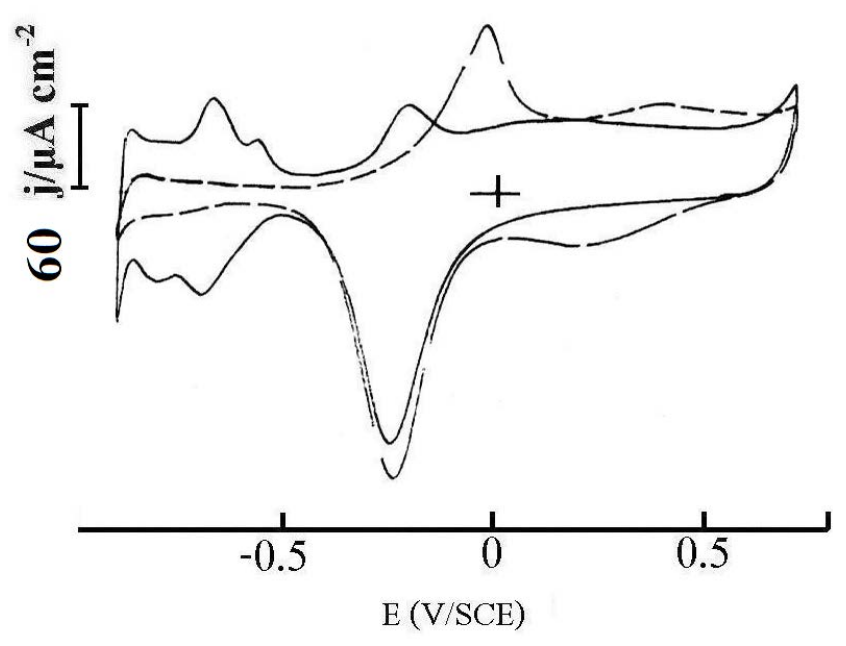

Figure 4. Cyclic voltammogram of $\mathrm{Pt} / 40 \% \mathrm{Au}$ in $0.1 \mathrm{M}$ $\mathrm{NaHCO}_{3}$ in absence (solid line) and presence (dashed line) $10^{-5} \mathrm{M} \mathrm{Sn}^{+2}$. Scan rate $50 \mathrm{mV} \mathrm{s}^{-1}$.

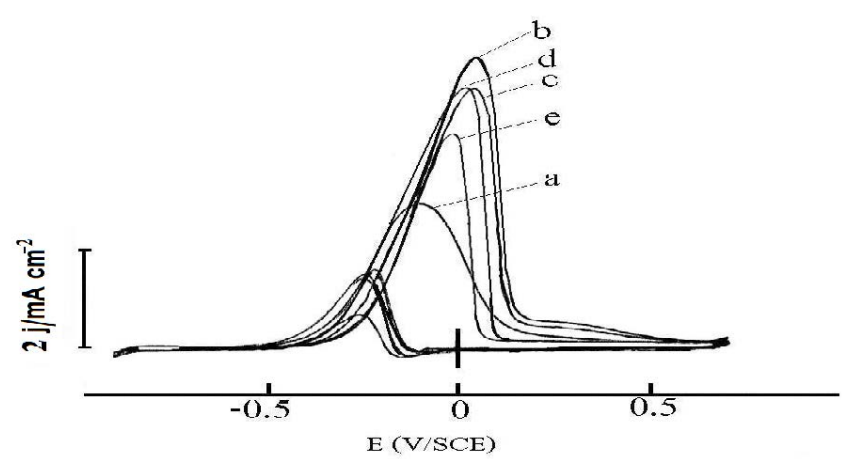

Figure 5. Cyclic voltammogram of $\mathrm{Pt} / 40 \% \mathrm{Au}$ in $0.5 \mathrm{M}$ $\mathrm{CH}_{3} \mathrm{OH}+0.1 \mathrm{M} \mathrm{NaHCO}_{3}$ in absence. (a) and presence of. (b) $10^{-7}$ M. (c) $10^{-5}$ M. (d) $10^{-3}$ M. (e) $10^{-2} \mathrm{M}$ of $\mathrm{Sn}^{+2}$. Scan rate $50 \mathrm{mV} \mathrm{s}^{-1}$. 


\section{Discussion and Conclusion}

We can use the following equation to demonstrate the effect of metal ions on $\mathrm{Pt} / \mathrm{Au}$ electrode :

$\mathrm{Au}-\mathrm{Pt}_{(\text {(subs) }}-[\mathrm{RCHOH}]_{\mathrm{ads}}+\mathrm{Au}-\mathrm{Pt}_{(\text {(subs) }}-\mathrm{M}(\mathrm{OH})_{\text {ads }}=$ products

where $\mathrm{M}$ is the metal and (subs) is the substrate. Hence, the catalytic properties of $\mathrm{Sn}$ on the methanol oxidation can be demonstrated by the modification of both $\theta_{\mathrm{O}}$ and $\theta_{\mathrm{OH}}$ as follow:

- If the foreign metal is easily oxidized than platinum, $\theta_{\mathrm{OH}}$ has satisfied values at potentials more negative than Pt anode. Hence, there is acceleration in methanol electrochemical oxidation according to the bi-functional theory.

On the basis of ligand effect theory, the properties of platinum anode in presence of $\mathrm{Sn}$ ions cannot be overcame.

- If $\mathrm{Sn}$ ions are not easily oxidized than Pt, both $\mathrm{q}_{\mathrm{OH}}$ and $\mathrm{q}_{\mathrm{O}}$ decreases due to the insufficient $\mathrm{Pt}$ surface sites towards methanol electrooxidation.

The catalytic activity of $\mathrm{Pt} / \mathrm{Au} / \mathrm{Sn}$ triplet electrode can be explained by the combination of both bifunctional theory of electro catalysis which explain the role of metal adatoms as in the above two points (1 and 2).

\section{Acknowledgement}

The researchers are appreciating to the deanship of scientific research, university of Tabuk for financial support

\section{References}

1. Dillon R, Srinivasan S, Arico AS, Antonucci V. International activities in DMFC R\&D: status of technologies and potential applications. Journal of Power Sources. 2004; 127(1-2):112-26. https://doi.org/10.1016/j.jpowsour.2003.09.032

2. Kamarudina SK, Achmada F, Daud WRW. Overview on the application of Direct Methanol Fuel Cell (DMFC) for portable electronic devices. International Journal of Hydrogen Energy. 2010; 34(16):6902-16. https://doi.org/10.1016/j. ijhydene.2009.06.013
3. Wang J, Yin G, Wang G, Wang Z, Gao Y. A novel Pt/ $\mathrm{Au} / \mathrm{C}$ cathode catalyst for direct methanol fuel cells with simultaneous methanol tolerance and oxygen promotion. Electrochemistry Communications. 2008; 10(6):831-4. https://doi.org/10.1016/j.elecom.2008.03.009

4. Baglio V, Di Blasi A, D’Urso C, Antonucci V, Arico AS, Ornelas R. Development of Pt and Pt-Fe catalysts supported on multiwalled carbon nanotubes for oxygen reduction in direct methanol fuel cells. Journal of Electrochemical Society. 2008; 155:829-33. https://doi. org/10.1149/1.2938368

5. Tang H, Chen JH, Wang MY, Nie LH, Kuang YF, Yao SZ. Controlled synthesis of platinum catalysts on Au nanoparticles and their electrocatalytic property for methanol oxidation. Applied Catalysis a General. 2004; 275(1):43-8. https://doi.org/10.1016/j.apcata.2004.07.018

6. Wang S, Kristian N, Jiang S, Wang X. Controlled synthesis of dendritic Au@Pt core-shell nanomaterials for use as an effective fuel cell electrocatalyst. Nanotechnology. 2009; 20(2):025605. https://doi.org/10.1088/09574484/20/2/025605 PMid:19417274

7. Park IS, Lee KS, Jung DS, Park HY, Sung YE. Electrocatalytic activity of carbon-supported $\mathrm{Pt}-\mathrm{Au}$ nanoparticles for methanol electro-oxidation. Electrochimica Acta. 2007; 52(18):5599-605. https://doi.org/10.1016/j.electacta.2006.12.068

8. Hogarth MP, Ralph TR. Catalysis for low temperature fuel cells. Platinum Metals Review. 2002; 46(1):146-64.

9. Selvarani G, Vinod Selvaganesh S, Krishnamurthy S, Kiruthika GVM, Sridhar P, Pitchumani S. A methanoltolerant carbon-supported Pt-Au alloy cathode catalyst for direct methanol fuel cells and its evaluation by DFT. Journal of Physical Chemistry C. 2009; 113(17):7461-8 https://doi. org/10.1021/jp810970d

10. Altamirano-Gutiérrez A, Jiménez-Sandoval $\mathrm{O}$, UribeGodínez J, Castellanos RH, Borja-Arco E, Olivares-Ramírez JM. Methanol resistant ruthenium electrocatalysts for oxygen reduction synthesized by pyrolysis of Ru3(CO)12 in different atmospheres. International Journal of Hydrogen Energy. 2009; 34(19):7983-94. https://doi.org/10.1016/j. ijhydene.2009.07.046

11. Zhiani M, Rezaei B, Jalili J. Methanol electro-oxidation on $\mathrm{Pt} / \mathrm{C}$ modified by polyaniline nanofibers for DMFC applications. International Journal of Hydrogen Energy. 2010; 35(17):9298-305. https://doi.org/10.1016/j. ijhydene.2010.03.050

12. Liao MJ, Wei ZD, Chen SG, Li L, Ji MB, Wang YQ. Ultra low Pt-loading electrode prepared by displacement of electrodeposited $\mathrm{Cu}$ particles on a porous carbon electrode. International Journal of Hydrogen 
Energy. 2010; 35(17):8071-9. https://doi.org/10.1016/j. ijhydene.2010.01.077

13. Habibi B, Pournaghi-Azar MH. Methanol oxidation on the polymer coated and polymer-stabilized Pt nano-particles: A comparative study of permeability and catalyst particle distribution ability of the PANI and its derivatives. International Journal of Hydrogen Energy. 2010; 35(17):9318-28. https:// doi.org/10.1016/j.ijhydene.2010.01.088

14. Godoi DRM, Perez J, Villullas HM. Effects of alloyed and oxide phases on methanol oxidation of $\mathrm{Pt}-\mathrm{Ru} / \mathrm{C}$ nanocatalysts of the same particle size. Journal of Physical Chemistry C. 2009; 113(19):8518-25. https://doi.org/10.1021/ jp8108804

15. Meza D, Morales U, Roquero P, Salgado L. Oxygen reduction on carbon supported Pt-W electrocatalysts. International Journal of Hydrogen Energy. 2010; 35(21):1211-4. https:// doi.org/10.1016/j.ijhydene.2009.07.021

16. García-Contreras MA, Fernández-Valverde SM, VargasGarcía JR, Cortés-Jácome MA, Toledo-Antonio JA, Ángeles-Chavez C. Pt, PtCo and PtNi electrocatalysts prepared by mechanical alloying for the oxygen reduction reaction in $0.5 \mathrm{M} \mathrm{H} 2 \mathrm{SO}$. International Journal of Hydrogen Energy. 2008; 33(22):6672-80. https://doi. org/10.1016/j.ijhydene.2008.07.025

17. Ramos-Sánchez G, Yee-Madeira H, Solorza-Feria O. PdNi electrocatalyst for oxygen reduction in acid media. International Journal of Hydrogen Energy. 2008; 33(13):3596-600. https://doi.org/10.1016/j. ijhydene.2008.03.004

18. Kumar SS, Phani KLN. Exploration of unalloyed bimetallic $\mathrm{Au}-\mathrm{Pt} / \mathrm{C}$ nanoparticles for oxygen reduction reaction. Journal of Power Sources. 2009; 187(1):19-24. https://doi. org/10.1016/j.jpowsour.2008.10.121

19. Li W, Ma H, Zhang J, Liu X, Feng X. Fabrication of gold nanoprism thin films and their applications in designing high activity electrocatalysts. Journal of Physical Chemistry C. 2009; 113(5):1738-45. https://doi.org/10.1021/ jp8085123

20. Du Y, Xu JJ, Chen HY. Ultrathin platinum film covered high-surface-area nanoporous gold for methanol electro-oxidation. Electrochemistry Communications. 2009; 11(8):1717-20. https://doi.org/10.1016/j.elecom.2009.07.004

21. Zhang J, Sasaki K, Sutter E, Adzic RR. Stabilization of platinum oxygen-reduction electrocatalysts using gold clusters. Science. 2007; 315(5809):220-2. https://doi.org/10.1126/ science.1134569 PMid:17218522

22. Guo S, Fang Y, Dong S, Wang E. High-efficiency and lowcost hybrid nanomaterial as enhancing electrocatalyst: spongelike Au/Pt core/shell nanomaterial with hollow cav- ity. Journal of Physical Chemistry C. 2007; 111(45):17104-9. https://doi.org/10.1021/jp075625z

23. Adzic RR, Zhang J, Sasaki K, Vukmirovic MB, Shao M, Wang JX. Platinum monolayer fuel cell electrocatalysts. Topics in Catalysis. 2007; 46(3-4):249-62. https://doi. org/10.1007/s11244-007-9003-x

24. Kiani A, Hatami S. Fabrication of platinum coated nanoporous gold film electrode: A nanostructured ultra low-platinum loading electrocatalyst for hydrogen evolution reaction. International Journal of Hydrogen Energy. 2010; 35(11):5202-9. https://doi.org/10.1016/j. ijhydene.2010.03.014

25. Hernández-Fernández $\mathrm{P}$, Rojas $\mathrm{S}$, Ocón $\mathrm{P}$, Gómez de la Fuente JL, San Fabián J, Sanza J. Influence of the preparation route of bimetallic Pt-Au nanoparticle electrocatalysts for the oxygen reduction reaction. Journal of Physical Chemistry C. 2007; 111(7):2913-23. https://doi. org/10.1021/jp066812k

26. Mott D, Luo J, Njoki PN, Lin Y, Wang L, Zhong CJ. Synergistic activity of gold-platinum alloy nanoparticle catalysts. Catalysis Today. 2007; 122(3):378-85. https://doi. org/10.1016/j.cattod.2007.01.007

27. Zeng J, Yang J, Lee JY, Zhou W. Preparation of carbonsupported core-shell Au-Pt nanoparticles for methanol oxidation reaction: The promotional effect of the Au core. Journal of Physical Chemistry B. 2006; 110(48):24606-11. https://doi.org/10.1021/jp0640979 PMid:17134221

28. Ge X, Wang R, Liu P, Ding Y. Platinum-decorated nanoporous gold leaf for methanol electrooxidation. Chemistry of Materials. 2007; 19(24):5827-9. https://doi.org/10.1021/ cm702335f

29. Yu Y, Hu Y, Liu X, Deng W, Wang X. The study of Pt@ $\mathrm{Au}$ electrocatalyst based on $\mathrm{Cu}$ underpotential deposition and $\mathrm{Pt}$ redox replacement. Electrochimica Acta. 2009; 54(11):3092-7. https://doi.org/10.1016/j.electacta.2008.12.004

30. Kristian N, Wang X. Ptshell-Aucore/C electrocatalyst with a controlled shell thickness and improved Pt utilization for fuel cell reactions. Electrochemistry Communications. 2008; 10(1):12-15. https://doi.org/10.1016/j.elecom.2007.10.011

31. Ge X, Wang R, Cui S, Tian F, Xu L, Ding Y. Structure dependent electrooxidation of small organic molecules on Pt-decorated nanoporous gold membrane catalysts. Electrochemistry Communications. 2008; 10(10):1494-7. https://doi.org/10.1016/j.elecom.2008.07.045

32. Zhao D, Xu BQ. Enhancement of Pt utilization in electrocatalysts by using gold nanoparticles. Angewandte Chemie International Edition. 2006; 45(30):4955-9. https://doi. org/10.1002/anie.200600155 PMid:16807963 
33. Brankovic SR, Wang JX, Adzic RR. Metal monolayer deposition by replacement of metal adlayers on electrode surfaces. Surface Science. 2001; 474(1-3):L173-79. https:// doi.org/10.1016/S0039-6028(00)01103-1

34. Herrero E, Buller LJ, Abru-a HD. Underpotential deposition at single crystal surfaces of $\mathrm{Au}, \mathrm{Pt}, \mathrm{Ag}$ and other materials. Chemical Reviews. 2001; 101(7):1897-930. https://doi. org/10.1021/cr9600363 PMid:11710235

35. Liu P, Ge X, Wang R, Ma H, Ding Y. Facile fabrication of ultrathin Pt overlayers onto nanoporous metal membranes via repeated $\mathrm{Cu}$ UPD and in situ redox replacement reaction. Langmuir. 2009; 25(1):561-7. https://doi.org/10.1021/ la8027034 PMid:19063640

36. Kristian N, Yu Y, Gunawan P, Xu R, Deng W, Liu X. Controlled synthesis of Pt-decorated Au nanostructure and its promoted activity toward formic acid electro-oxidation. Electrochimica Acta. 2009; 54(21):4916-24. https://doi. org/10.1016/j.electacta.2009.04.018 